\title{
Penerapan Teknologi Pembangkit Listrik Tenaga Surya Untuk Mendukung Terwujudnya Kemandirian Energi Listrik Di Pesantren Raudhatul Ishlah
}

\author{
Sugeng Purwanto ${ }^{1}$; Sofitri Rahayu ${ }^{2}$; Hasna Satya Dini $^{3}$; Pawenary ${ }^{4}$ \\ 1, 2,3,4 Institut Teknologi PLN \\ ${ }^{1}$ sugeng.purwanto@itpln.ac.id
}

\begin{abstract}
This community service program is a development and continuation of previous program activities that take the theme of Solar Power Plant Design Training in Madrasah Aliyah Darussalam Parung Bogor with a focus on designing simple solar power plant for catfish ponds that use battery, DC lights, and 5 WP solar panels. The focus on this community service program is training on the application of appropriate technology for solar power generation with a household group $R-1 / T R$ 2200 VA that uses solar panels, batteries, and controller. This program activity is divided into several stages, including site survey, socialization, solar power generation, and testing of solar power plant component, training, system installation, component assembly, and program evaluation. The first stage is a site survey conducted to obtain preliminary information about electricity usage patterns in the Raudhatul Ishlah. The second stage is the socialization of the program to the students and the community. The next stage is the solar power generation component testing to find out the quality and the identification of its components. Then the fourth stage is the introduction of its technology to give participants a greater understanding. The fifth stage is the assembly and installation of solar power generation components. The last stage is program evaluation using the interview and filling out the questionnaire. This program is held at Raudhatul Ishlah. This activity is the application technology which is very useful in the provision of electricity independently to support various activities in Islamic boarding schools and communities.
\end{abstract}

Keywords: solar power generation, hybrid power generation, load supply regulation, automatic transfer switch, photovoltaic

\section{ABSTRAK}

Program pengabdian kepada masyarakat (PKM) ini merupakan pengembangan dan kelanjutan dari kegiatan PKM sebelumnya yang mengambil tema tentang Pelatihan Rancang Bangun Pembangkit Listrik Tenaga Surya di Madrasah Aliyah Darussalam Parung Bogor dengan fokus kepada perancangan PLTS sederhana untuk kolam benur lele yang menggunakan komponen baterai, lampu DC dan panel surya 5 WP. Sedangkan fokus pada program PKM ini berupa pelatihan penerapan teknologi tepat guna pembangkit listrik tenaga surya (PLTS) dengan skala rumah tangga golongan $R-1 / T R 2200$ VA yang menggunakan beberapa peralatan dengan teknologi tepat guna seperti panel surya, baterai dan controller (ATS - Automatic Transfer Switch). Kegiatan PKM ini terbagi dalam beberapa tahapan, meliputi: survei lokasi, sosialisasi, pengujian komponen PLTS, pelatihan, perakitan dan instalasi sistem serta evaluasi program. Tahap pertama adalah survei lokasi yang dilakukan untuk mendapatkan informasi awal mengenai pola pemakaian listrik di Pesantren Raudhatul Ishlah. Tahap kedua adalah sosialisasi kegiatan PKM kepada para santri dan masyarakat. Tahap selanjutnya adalah tahap pengujian komponen yang bertujuan untuk mengetahui kualitas dari PLTS, serta identifikasi komponen PLTS. Kemudian tahap keempat yaitu pengenalan teknologi PLTS untuk memberi pemahaman lebih mengenai teknologi PLTS. Tahap kelima adalah perakitan dan pemasangan (install) komponen PLTS secara keseluruhan. Tahap terakhir dalam kegiatan PKM ini adalah evaluasi program dengan menggunakan metode interview dan pengisian kuisioner. Kegiatan PKM ini dipusatkan di Pondok Pesantren Raudhatul Ishlah, Kelurahan Serua, Tengerang Selatan. Kegiatan ini merupakan penerapan teknologi PLTS yang sangat berguna dalam 
Terang: Jurnal Pengabdian Pada Masyarakat Menerangi Negeri

e-ISSN: $2655-5948$

Vol. 3, No. 2, Juli 2021

P-ISSN: 2655-5956

DOI: https://doi.org/10.33322/terang.v3i2.1034

Hal. $200-210$

pengadaan listrik secara mandiri untuk mendukung berbagai aktivitas di dalam pondok pesantren dan masyarakat.

Kata kunci: pembangkit listrik tenaga surya, pembangkit listrik tenaga hibrid, pengaturan suplai beban, automatic transfer switch, photovoltaic 


\section{PENDAHULUAN}

Sebagai salah satu sumber energi, energi listrik merupakan energi yang paling banyak dibutuhkan oleh masyarakat luas, baik di perumahan ataupun industri kecil. Kebutuhan akan energi listrik bagi masyarakat semakin meningkat dari hari ke hari. Pemenuhan energi, terutama energi listrik merupakan permasalahan semua Negara di dunia dan merupakan komoditas yang strategis karena menyangkut hajat hidup manusia sebagai urat nadi kehidupan dari semua sektor kehidupan pada saat sekarang ini [1].

Dengan makin meningkatnya kemajuan teknologi maka kebutuhan masyarakat terhadap energi listrik juga semakin meningkat. Energi listrik juga banyak digunakan dalam mendukung kegiatan sehari-hari masyarakat, baik di dalam dunia pendidikan, pekerjaan dan industri sehingga tingkat ketergantungan masyarakat, terutama masyarakat perkotaan, terhadap tenaga listrik sudah sangat besar [2].

Seiring dengan makin meningkatnya penggunaan bahan bakar fosil untuk mendukung perkembangan teknologi yang semakin meningkat dari tahun ke tahun, mengakibatkan cadangan bahan bakar fosil makin berkurang secara signifikan. Menipisnya cadangan bahan bakar fosil memberikan dampak kepada pembangkit listrik konvensional yaitu dengan makin meningkatnya biaya opersional pembangkit sehingga pada akhirnya secara tidak langsung hal tersebut dapat menjadi beban bagi masyarakat sebagai konsumen listrik yang paling loyal. Selain itu karena ketidakseimbangan antara pasokan listrik dan beban yang makin meningkat memberikan dampak terjadinya pemadaman listrik yang semakin seing sehingga dapat menimbulkan dampak sosial yang semakin meningkat seperti mengganggu kegiatan warga masyarakat di malam hari seperti belajar dan pengamanan lingkungan serta dapat merusak peralatan listrik rumah tangga.

Untuk menjawab permasalahan di atas maka pemerintah mengeluarkan kebijakan mengenai Energi Baru Terbarukan (EBT) yaitu tercapainya bauran energi EBT sebesar 23\% pada tahun 2025[3]. Hal tersebut dilakukan pemerintah dalam upaya membangun kelistrikan nasional yang berkualitas dan mandiri dengan harga terjangkau bagi masyarakat. Tetapi untuk mencapai bauran energi sebesar 23\% pada tahun 2025 merupakan sesuatu yang tidak mudah karena masih sangat kurangnya pemahaman masyarakat terhadap energi baru terbarukan sehingga untuk mencapai kemandirian energi listrik melalui EBT, salah satu caranya adalah dengan memberikan pemahaman yang komprehensif kepada masyarakat mengenai EBT terutama mengenai Pembangkit Listrik Tenaga Surya (PLTS). Sumber energi baru terbarukan mempunyai peran yang sangat vital bagi kehidupan manusia dalam memenuhi kebutuhan energi, terutama energi listrik, di masa yang akan dating [4].

PLTS merupakan energi alternatif yang tidak memberikan dampak negative terhadap lingkungan sehingga penduduk perkotaan dapat menikmati udara yang lebih bersih [5].

PLTS merupakan teknologi tepat guna yang sangat mudah dan sudah banyak diplikasikan ke dalam kehidupan sehari-hari, antara lain pompa air, penerangan jalan, alat pengering dan penangkap ikan, solar home system (SHS) dan lain-lain [6]. Walaupun sudah banyak diaplikasikan di dalam berbagai peralatan listrik tetapi pemahaman masyarakat kepada PLTS masih kurang atau belum memadai sehingga minat masyarakat untuk mempergunakan PLTS sebagai sumber energi listrik dalam mendukung kegiatan sehari-hari masih sangat kurang.

Penerapan PLTS sebagai sumber energi alternative mempunyai potensi energi yang sangat baik yaitu reta-rata menghasilkan $4,5 \mathrm{kWh} / \mathrm{m}^{2} /$ hari atau setara dengan yang dihasilkan oleh panel surya dengan kapasitas $100 \mathrm{Wp}$ (watt peak) dangan luas permukaan $1 \mathrm{~m}^{2}$ yaitu sebesar $675 \mathrm{Wh}$ (watt hour) [7]. 
Dalam aplikasinya, sistem pengoperasian dan pemeliharaan SHS tidak banyak diketahui oleh masyarakat Indonesia pada umumnya, sehingga peningkatan pengetahuan dan keterampilan mengenai PLTS dan SHS menjadi sangat penting [8].

Oleh karena itu dibutuhkan sosialisasi dan pelatihan yang menyeluruh tentang penggunaan dan pemanfaatan PLTS sebagai sumber energi listrik kepada masyarakat. Kegiatan pelatihan ini mencakup beberapa tahapan kegiatan, yaitu pengenalan teknologi PLTS, identifikasi komponen PLTS, perakitan dan pemasangan dan tahap akhir adalah pengujian. Tahap pertama merupakan pengenalan teknologi PLTS dimaksudkan untuk memberi pemahaman yang baik kepada masyarakat mengenai teknologi ini. Tahap kedua adalah identifikasi komponen PLTS yang akan menjelaskan fungsi dan cara kerja komponen di dalam PLTS. Setelah itu akan dilanjutkan ke dalam tahap ketiga yaitu perakitan dan pemasangan komponen PLTS secara keseluruhan baik komponen internal maupun eksternal. Dan tahap terakhir adalah tahap pengujian yang bertujuan untuk mengetahui kualitas dari PLTS yang telah dipasang, mencakup pengujian tegangan dan arus baik input maupun output. Tahapan dalam kegiatan PKM saling berhubungan satu sama lain sehingga diharapkan para peserta pelatihan dapat dengan mudah menyerap materi pelatihan yang diberikan.

Fokus dan prioritas pada program PKM ini berupa pelatihan penerapan teknologi tepat guna PLTS dengan skala rumah tangga (solar home system) golongan R-1/TR 2200 VA yang menggunakan berbagai peralatan dengan teknologi tepat guna seperti panel surya, baterai dan controller (ATS - Automatic Transfer Switch). Adapun komponen ATS terdiri dari mini circuit breaker (MCB), magnetic contactor (MC), magnetic relay, inverter, solar charge controller (SCC), lampu indikator, voltmeter dan amperemeter digital, dan saklar push button on/off.

Panel surya (photovoltaic - PV), baterai, dan sistem pengaturan suplai beban (automatic transfer switch - ATS) termasuk di dalam sistem pembangkit listrik tenaga hybrid (PLTH) yaitu gabungan dari beberapa pembangkit. ATS merupakan komponen yang sangat penting di dalam PLTH karena berfungsi untuk melakukan pengaturan suplai beban secara otomatis antara energi listrik dari panel surya, baterai dan PLN [9].

Kegiatan pelatihan ini akan difokuskan kepada para santri dan masyarakat yang berdomisili di sekitar Pondok Pesantren Raudhatul Ishlah, Kelurahan Serua, Tangerang Selatan. Dengan adanya pelatihan ini diharapkan para peserta pelatihan mendapatkan pemahaman yang lebih baik mengenai teknologi PLTS sehingga dapat menerapkan teknologi PLTS dalam mendukung kegiatan sehari-hari sehingga dapat mengurangi beban masyarakat dalam hal pembiayaan untuk memenuhi kebutuhan energi listrik berbahan bakar fosil dan dapat mewujudkan kemandirian energi listrik di masyarakat [10].

\section{METODE PELAKSANAAN}

Langkah-langkah pengerjaan harus disusun berdasarkan kebutuhan dan dijadikan sebagai pedoman sehingga pengerjaan yang dilakukan sesuai dengan jadwal yang telah disusun [8]. Untuk mencapai tujuan yang telah dijelaskan diatas, maka ditempuh langkah-langkah sebagai berikut:

a. Menghubungi pemerintah daerah setempat untuk mendiskusikan topik program yang akan dilaksanakan. Target luaran berupa dukungan dari pemerintah daerah berupa penyediaan fasilitas gedung untuk seminar dan pelatihan.

b. Menghubungi stakeholder yakni Pesantren Raudhatul Ishlah Tangerang Selatan untuk mensosialisasikan program yang akan diterapkan dan survey lokasi pelarihan. Target luaran berupa dukungan dari para stakeholder dalam mensukseskan acara seminar dan pelatihan. Support dari para stakeholder bagi sustainability program ini sangat diperlukan.

c. Sosialisasi kepada santri dan masyarakat tentang pemanfaatan teknologi pembangkit listrik 
tenaga surya (PLTS) melalui seminar dan pelatihan. Sosialisasi ini bertujuan untuk memberikan persamaan pemahaman mengenai maksud dan tujuan, jadwal dan prosedur kegiatan beserta implementasi dan jaminan keberlanjutan kegiatan pengabdian kepada masyarakat ini [11]. Seminar dan pelatihan yang diadakan bertema "Penerapan Teknologi Pembangkit Listrik Tenaga Surya (PLTS) Untuk Mendukung Terwujudnya Kemandirian Energi Listrik" yang akan dilaksanakan di Pondok Pesantren Raudhatul Ishlah, Tangerang Selatan. Untuk persiapan penyelenggaraan Seminar ini diperlukan waktu paling tidak 1 bulan sebelum pelaksanaan Seminar. Waktu tersebut diperlukan untuk menyebarkan undangan bagi peserta dan para stakeholder serta untuk mempersiapkan fasilitas yang diperlukan untuk acara. Stakeholder yang akan diundang adalah Pemda setempat dan Pondok Pesantren Raudhatul Ishlah, Kelurahan Serua, Tengerang Selatan. Sekitar 20 santri dan masyarakat sekitar pondok akan diundang untuk mengikuti seminar sosialisasi tersebut. Dengan kegiatan sosialisasi ini juga diharapkan dapat memberikan pemahaman mengenai pemanfaatan teknologi PLTS. Dalam penelitian [12] menjelaskan bahwa dalam rangka mendorong terciptanya pengetahuan dan kesadaran warga terhadap lingkungan maka harus dilakukan kegiatan yang berbasis kepada lingkungan hidup sehingga akan terbentuk sebuah karakter yang peduli kepada pelestarian lingkungan hidup.

d. Identifikasi komponen dan perakitan serta pengujian dari komponen PLTS. Untuk identifikasi komponen dan perakitan komponen diperlukan waktu sekitar 4 bulan dari identifikasi kapasitas dan fungsi dari setiap komponen sampai dengan pengukuran input dan output tegangan dan arus dari setiap komponen. Semua proses identifikasi komponen dilakukan di Laboratorium Mesin-mesin Listrik Lt 6 Departemen Elektro. Setelah spesifikasi komponen yang tepat didapat, maka semua komponen PLTS dirakit, kemudian diakukan pengujian tegangan dan arus input maupun output pada semua komponen. Setelah itu dilakukan pengujian pada panel surya untuk mengetahui seberapa besar arus dan tegangan yang dihasilkan. Pengujian panel surya dilakukan pada jam 7 pagi sampai jam 4 sore, selama 7 hari beruturut-turut.

e. Metode yang diterapkan di dalam pelatihan dan pembekalan teknologi PLTS kepada para peserta dimaksudkan agar para peserta dapat memanfaatkan teknologi PLTS secara mandiri. Pelatihan dan pembekalan yang diberikan disesuaikan dengan karakteristik dari masyarakat setempat yang memiliki pemahaman yang salah atau kurang memadai mengenai teknologi yang akan diberikan [13]. Kegiatan pelatihan ini akan dilaksanakan di Aula Pondok Pesantren Raudhoh Ishlah, Tengerang Selatan. Pada kegiatan ini akan diberikan penjelasan secara detail mengenai fungsi dari komponen yang digunakan, cara merakit komponen-komponen PLTS dan ATS, dan pelatihan pemeliharaan PLTS, seperti pengecekan tegangan baterai dan panel surya sebagai bagian dari sistem pemeliharan (maintenance system).

f. Instalasi atau pemasangan PLTS di Pondok Pesantren Raudhoh Ishlah. Kegiatan instalasi ini dilakukan sebagai finalisasi dari seminar dan pelatihan yang telah diadakan. Hal tersebut dilakukan untuk memperlihatkan kepada para peserta bahwa PLTS dapat dijadikan sebagai alternatif energi listrik untuk mewujudkan kemandirian energi listrik di Indonesia. Dalam penelitian [14] bahwa pemasangan PLTS di pesantren memberikan manfaat yang sangat besar terutama untuk mengurangi ketergantungan terhadap listrik PLN dalam jangka panjang, dan dapat ikut berpartisipasi mengurangi efek rumah kaca.

g. Evaluasi diperlukan untuk menilai keberhasilan program ini. Evaluasi merupakan sebuah alat ataupun prosedur yang digunakan untuk mengetahui dan mengukur sesuatu sesuai 
dengan cara atau ketentuan-ketentuan yang sudah ditentukan sebelumnya [15]. Evaluasi dilakukan selama satu bulan terakhir dari program pengabdian masyarakat ini. Metode yang akan dilakukan adalah dengan survei dan kuesioner serta interview kepada para peserta pelatihan dan juga stakeholder. Parameter keberhasilan program ini adalah apabila:

- $80 \%$ peserta yang diundang Seminar dan Pelatihan dapat hadir.

- Terlaksananya seluruh kegiatan sosialisasi dan pelatihan penerapan teknologi pembangkit listrik tenaga surya (PLTS) di Pondok Pesantren Raudhatul Ishlah.

- $40 \%$ santri dan masyarakat yang mengikuti pelatihan mampu menyerap dan menerapkan teknologi pembangkit listrik tenaga surya (PLTS).

- Pernyataan kepuasan dari peserta pelatihan dan pemerintah setempat.

\section{HASIL DAN PEMBAHASAN}

Berikut adalah skematik diagram proses kegiatan pengabdian masyarakat yang akan dilakukan:

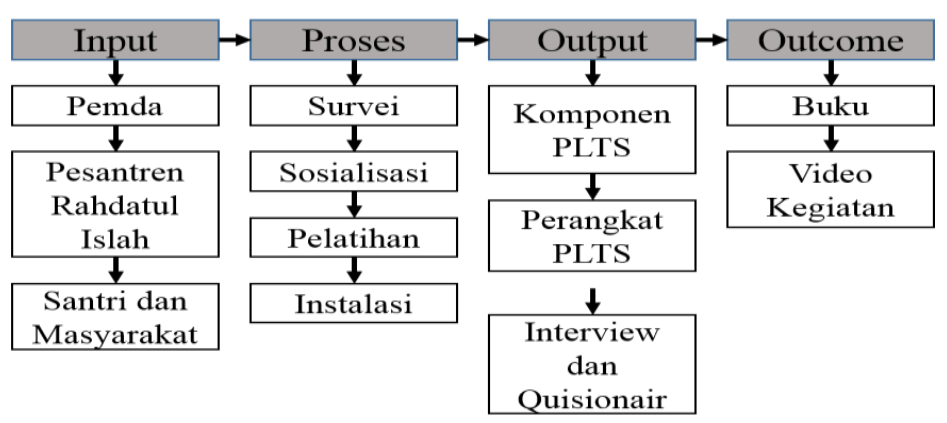

Gambar 1. Skematik diagram proses kegiatan pengabdian masyarakat

Seperti yang disebutkan di dalam skematik diagram proses kegiatan pengabdian masyarakat, Gambar 1., maka sebelum dilaksanakannya pelatihan, maka terlebih dahulu dilakukan silaturahmi kepada pemda atau para tokoh lingkungan setempat untuk mendiskusikan topik program yang akan dilaksanakan dan untuk mendapatkan dukungan berupa penyediaan fasilitas gedung untuk seminar dan pelatihan serta silaturahmi dengan pimpinan pesantren Raudhatul Ishlah untuk survey lokasi.

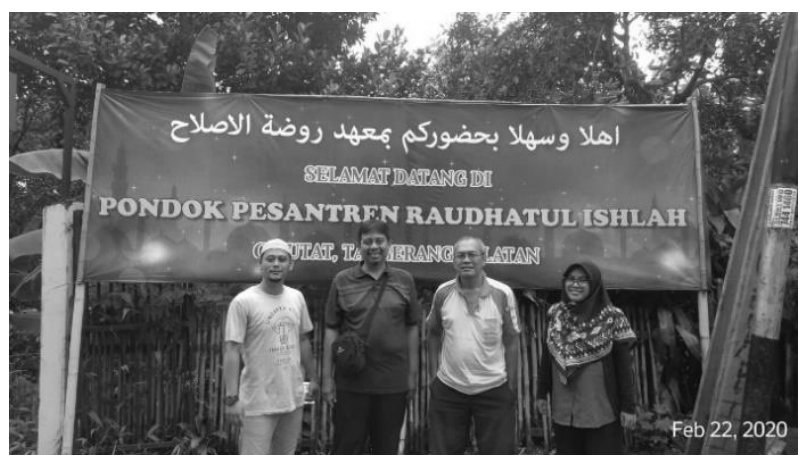

Gambar 2. Silaturahmi Tim IT PLN dengan Pimpinan Pondok Pesantran Raudhatul Ishlah dan Tokoh Lingkungan Setempat. 


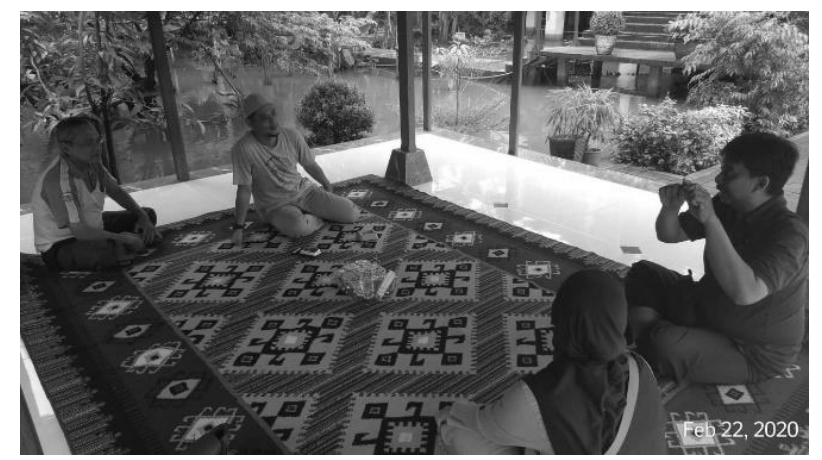

Gambar 3. Mendiskusikan Topik Program yang akan dilaksanakan

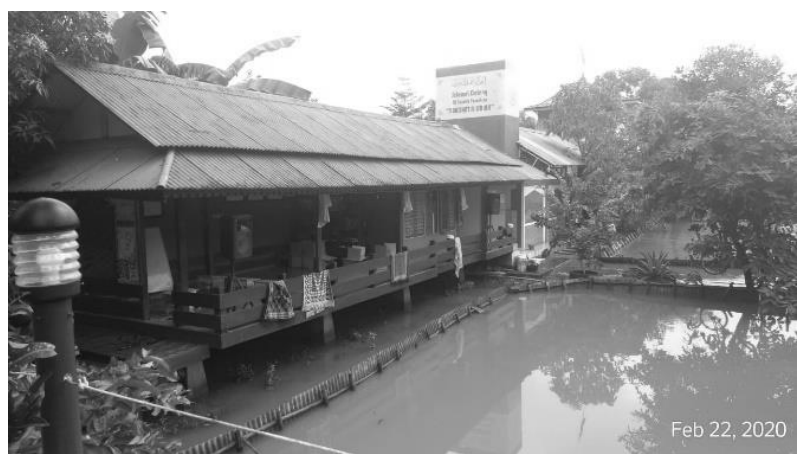

Gambar 4. Survei Lokasi Pondok Pesantran Raudhatul Ishlah

Sosialisasi mengenai pemanfaatan teknologi pembangkit listrik tenaga surya (PLTS) kepada santri dan masyarakat dilakukan melalui seminar dan pelatihan. Undangan kepada para santri dan masyarakat dilakukan selama satu bulan sebelum seminar dan pelatihan dilaksanakan. Hal tersebut dilakukan untuk mengantisipasi agar para santri dan masyarakat dapat datang tanpa halangan ke seminar dan pelatihan yang akan diadakan. Seminar dan pelatihan ini akan dilakukan di dalam dua tahap, yaitu tahap pertama dan tahap kedua. Tahap pertama diberikan penjelasan mengenai prinsip kerja dari pembangkit listrik tenaga surya (PLTS) secara keseluruhan dan detail. Sedangkan tahap kedua diberikan pelatihan mengenai identifikasi komponen (fungsi dan cara kerja komponen) PLTS dan Automatic Transfer Switch (ATS) serta perakitan komponen. Peserta seminar dan pelatihan berjumlah 15 orang peserta yang terdiri para santri dan masyarakat umum yang berdomisili di sekitar pesantren.

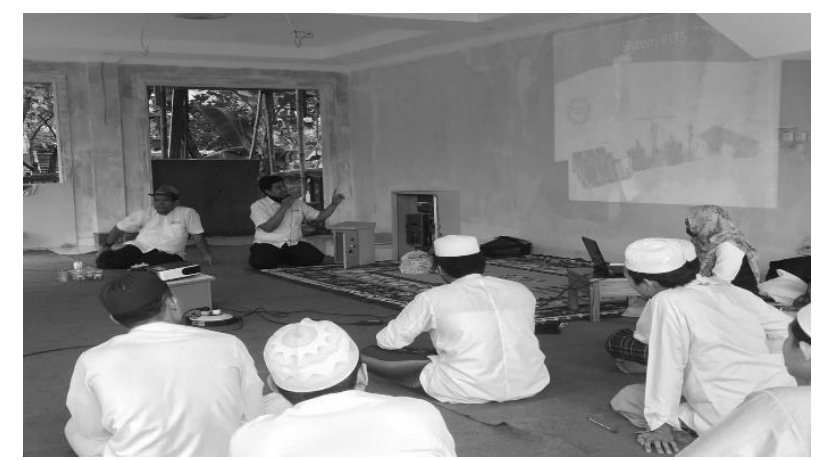

Gambar 5. Seminar PLTS di Pondok Pesantran Raudhatul Ishlah 

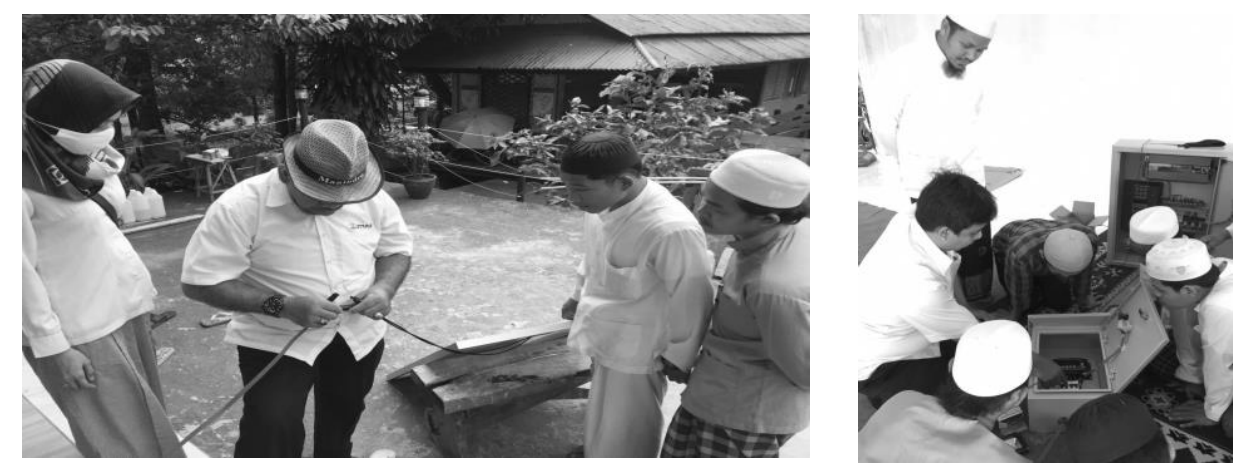

Gambar 6. Pelatihan PLTS di Pondok Pesantran Raudhatul Ishlah

Sebelum diadakan seminar dan pelatihan maka para peserta diberikan kuesioner untuk mengetahui minat dan pengetahuan para peserta seminar dan pelatihan mengenai PLTS dan ATS. Sesudah diadakan seminar dan pelatihan maka para peserta juga diberikan kuesioner untuk mengetahui apakah para peserta dapat memahami dan menyerap materi yang diberikan sehingga mendapatkan pengetahuan tentang PLTS dan ATS secara komprehensif. Dari kuesioner yang dikembalikan oleh peserta seminar dan pelatihan, sebelum seminar dan pelatihan dimulai, didapatkan beberapa data antara lain bahwa hampir sebagian peserta belum mengetahui mengenai Pembangkit Listrik Tenaga Surya (PLTS) atau sekitar 73\% peserta dan Automatic Transfer Switch (ATS) sekitar $80 \%$ peserta. Semua atau $100 \%$ peserta mengatakan bahwa investasi di bidang PLTS dan ATS adalah mahal. Sebelum seminar dan pelatihan dilakukan, hanya sekitar $6,67 \%$ peserta yang memahami cara kerja PLTS tetapi setelah seminar dan pelatihan dilakukan, peserta yang memahami cara kerja PLTS mengalami peningkatan menjadi sekitar 53,3\%.

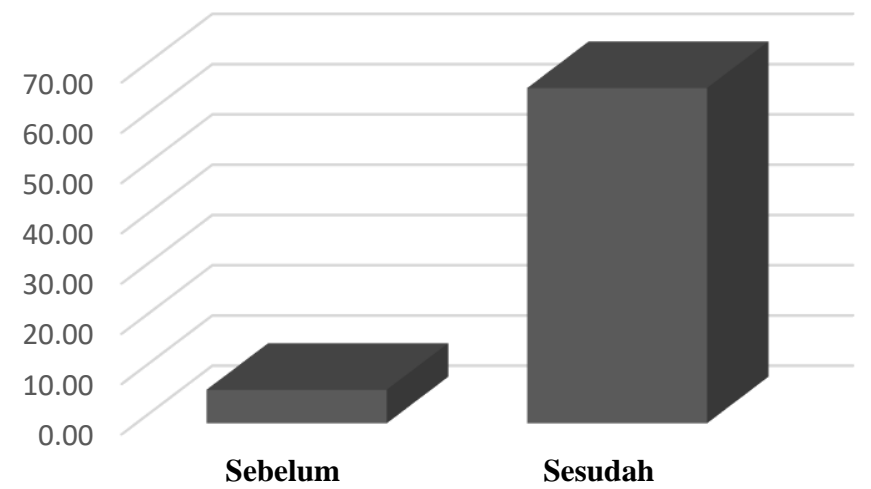

Gambar 7. Pemahaman peserta mengenai cara kerja PLTS sebelum dan sesudah pelatihan

Kegatan ini diakhiri dengan pemasangan PLTS di Pesantren Raudhatul Ishlah, Tangerang Selatan. 

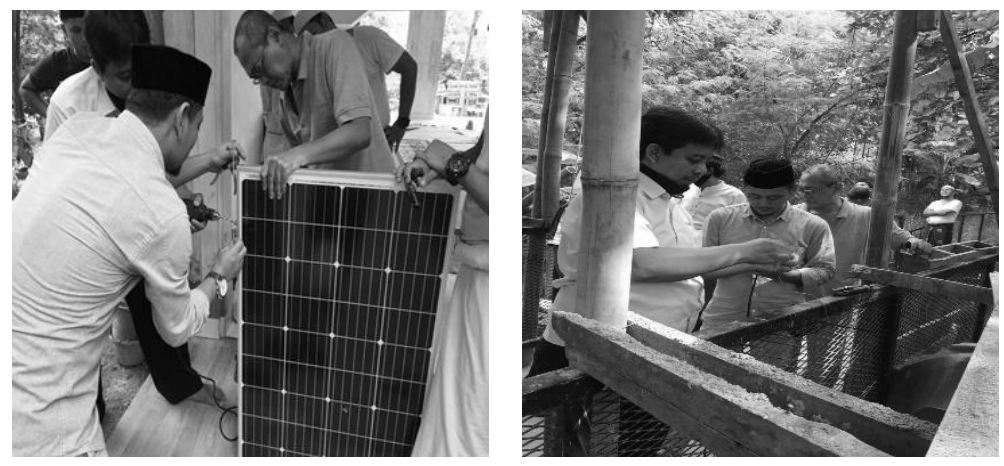

Gambar 8. Pemasangan PLTS

Dari data yang didapatkan dari kuesioner yang telah dikembalikan oleh peserta seminar dan pelatihan PLTS bahwa semua peserta berkeyakinan bahwa Pembangkit Listrik Tenaga Surya (PLTS) merupkan energi masa depan dan ramah lingkungan serta dengan teknologi tinggi yang dimilikinya, PLTS dapat menggantikan peran pembangkit listrik konvensional yang dikelola oleh PLN untuk digunakan di perumahan dan perkantoran sehinga dapat terwujudnya kemandirian energi di tengahtengah masyarakat.

Melalui kegiatan seminar dan pelatihan "Penerapan Teknologi Pembangkit Listrik Tenaga Surya (PLTS) Untuk Mendukung Terwujudnya Kemandirian Energi Listrik di Pesantren Raudhatul Ishlah, Tangerang Selatan" ini maka dapat dilakukan evaluasi terhadap seluruh proses penyelenggaraan seminar dan pelatihan untuk mengetahui informasi mengenai tingkat capaian program yang telah dilakukan (Tabel 1.).

Tabel 1. Evaluasi Kegiatan Seminar dan Pelatihan PLTS di Pesantren Raudhatul Ishlah,

Tangerang Selatan

\begin{tabular}{|c|l|l|}
\hline No & \multicolumn{1}{|c|}{ Item } & \multicolumn{1}{|c|}{ Evaluasi } \\
\hline 1 & $\begin{array}{l}80 \% \text { peserta yang diundang Seminar } \\
\text { dan Pelatihan dapat hadir. }\end{array}$ & $\begin{array}{l}\text { Seluruh peserta yang diundang hadir pada seminar dan } \\
\text { pelatihan PLTS }\end{array}$ \\
\hline 2 & $\begin{array}{l}\text { Terlaksananya seluruh kegiatan } \\
\text { sosialisasi dan pelatihan penerapan } \\
\text { teknologi pembangkit listrik tenaga } \\
\text { surya (PLTS) di Pondok Pesantren } \\
\text { Raudhatul Ishlah. }\end{array}$ & $\begin{array}{l}\text { Seluruh kegiatan yang direncanakan dapat berjalan } \\
\text { dengan baik dan sesuai dengan yang direncanakan. }\end{array}$ \\
\hline 3 & $\begin{array}{l}40 \% \text { santri dan masyarakat yang } \\
\text { mengikuti pelatihan mampu menyerap } \\
\text { dan menerapkan teknologi pembangkit } \\
\text { listrik tenaga surya (PLTS). }\end{array}$ & $\begin{array}{l}\text { Sekitar 66,7\% peserta mengetahui cara kerja PLTS, } \\
\text { yaitu mengalami peningkatan dari sebelum seminar } \\
\text { dan pelatihan PLTS dilakukan yaitu sekitar 6,7\%. } \\
\text { Sebanyak 93,3\% peserta mengatakan teknologi } \\
\text { PLTS mudah untuk dipelajari dan diaplikasikan. } \\
\text { Semua peserta berkeyakinan bahwa PLTS dapat } \\
\text { menggantikan peran pembangkit konvensional } \\
\text { (berbahan bakar fosil) di masa yang akan datang. }\end{array}$ \\
\hline 4 & $\begin{array}{l}\text { Pernyataan kepuasan dari peserta } \\
\text { pelatihan dan pemerintah setempat. }\end{array}$ & $\begin{array}{l}\text { Kerjasama antara Institut Teknologi PLN dan } \\
\text { Pesantren Raudhatul Ishlah dapat dilanjutkan pada } \\
\text { masa-masa yang akan dating. }\end{array}$ \\
\hline
\end{tabular}




\section{KESIMPULAN DAN SARAN}

Pembangkit listrik tenaga surya (PLTS) merupakan sumber energi alternative, tapat guna, ramah lingkungan dan mudah untuk diaplikasikan di tengah masyarakat serta dapat memberikan manfaat yang banyak kepada masyarakat sehingga PLTS dapat menggantikan peran pembangkit listrik konvensional di masa yang akan dating. Santri dan masyarakat di sekitar Pesantren Raudhatul Ishlah, Kota Tangerang Selatan sangat antusias mengikuti seminar dan pelatihan PLTS melalui kegiatan PKM ini, terbukti dari respon yang baik dan hasil kuesioner yang memuaskan.

Diharapkan seminar dan pelatihan PLTS ini dapat menambah pengetahuan masyarakat tentang sumber energi terbarukan serta cara perawatan dan pemeliharaan PLTS yang telah terpasang.

\section{UCAPAN TERIMAKASIH}

Penulis mengucapkan terima kasih kepada Institut Teknologi PLN (IT PLN) yang telah memberikan dukungan berupa dana Pengabdian Kepada Masyarakat sehingga kegiatan yang penulis lakukan dapat berjalan dengan baik.

\section{DAFTAR PUSTAKA}

[1] Kementerian ESDM, "Jurnal Energi," 2016.

[2] H. Asy'ari, A. Rozaq, and F. S. Putra, "Pemanfaatan Solar Cell Dengan Pln Sebagai Sumber Energi Listrik Rumah Tinggal," Emitor, vol. 14, no. 01, pp. 33-39, 2014.

[3] R. PLN, "RUPTL PLN 2018-2025," pp. 54-67, 2018.

[4] A. I. Ramadhan, E. Diniardi, and S. H. Mukti, "Analisis Desain Sistem Pembangkit Listrik Tenaga Surya Kapasitas 50 WP,” Tek. 37 (2), 2016, 59-63, vol. 11, no. 2, pp. 61-78, 2016.

[5] M. Naim and S. Wardoyo, "Rancangan Sistem Kelistrikan PLTS on Grid 1500 Watt Dengan Back Up Battery di Desa Timampu Kecamatan Towuti,” Din. J. Ilm. Tek. Mesin, vol. 8, no. 2, pp. 11-17, 2017.

[6] M. Rif'an, S. H. Pramono, M. Shidiq, R. Yuwono, H. Suyono, and F. Suhartati, "Optimasi Pemanfaatan Energi Listrik Tenaga Matahari Di Jurusan Teknik Elektro Universitas Brawijaya," J. EECCIS, vol. 6, no. 1, pp. 44-48, 2012.

[7] K. Akhmad, "Pembangkit Listrik Tenaga Surya Dan Penerapannya Untuk Daerah Terpencil," J. Ilm. Din. Rekayasa, vol. 1, no. 1, pp. 28-33, 2005.

[8] R. Sianipar, "Dasar Perencanaan Pembangkit Listrik Tenaga Surya," vol. 11, no. 2, pp. 61-78, 2014.

[9] R. Rizaldi and S. U. Djufri, "Perancangan Ats (Automatic Transfer Switch) Satu Phasa Menggunakan Kontrol Berbasis Relay Dan Time Delay Relay (Tdr)," J. Electr. Power Control Autom., vol. 1, no. 2, p. 59, 2018.

[10] I. M. A. Nugraha, I. A. D. Giriantari, and I. N. S. Kumara, "Studi Dampak Ekonomi dan Sosial PLTS Sebagai Listrik Pedesaan Terhadap Masyarakat Desa Ban Kubu Karangasem," Pros. Conf. Smart-Green Technol. Electr. Inf. Syst., 2013.

[11] A. Husaini, K. Amrullah, D. Suherman, K. Kunci, and K. Kabawetan, "Inovasi Suplemen Pakan Sakura Blok Plus untuk Meningkatkan Produksi Susu Sapi Perah Suplemen Sakura Blok Plus merupakan modifikasi dari formula UMMB ( Urea Mollases Multinutrien Block ) dengan menggantikan molasses menggunakan sisa pembuatan gula aren , t," vol. 5, no. 3, pp. 388-397, 2019.

[12] Y. Afriyeni, "Pembentukan Karakter Anak Untuk Peduli Lingkungan Yang Ada Di Sekolah Adiwiyata Mandiri SDN 6 Pekanbaru Yeni Afriyeni Sekolah Tinggi Persada Bunda Pekanbaru," J. Pendidik. Anak Usia Dini, vol. 1, no. 2, 2018. 
[13] H. A. Ekamawanti and H. Herkulana, "Inisiasi Teknologi Hayati Pada Petani Untuk Mendukung Revegetasi Lahan Bekas Perladangan,” JPPM (Jurnal Pengabdi. dan Pemberdaya. Masyarakat), vol. 3, no. 2, p. 185, 2019.

[14] W. Priharti, E. Kurniawan, and D. K. Silalahi, "Penyuluhan Penggunaan Listrik dari Sumber Energi Surya Di Pesantren Al Mukarramah Kabupaten Bandung," ETHOS (Jurnal Penelit. dan Pengabdian), 2019.

[15] A. D. Muryadi, "MODEL EVALUASI PROGRAM DALAM PENELITIAN EVALUASI," J. Ilm. PENJAS, vol. 3, no. 1, p. 87, 2017. 